\title{
The Community Structure of Macrozoobenthos and Its Temporal Change on the Gapo Artificial Tidal Flat in Masan Bay, Korea
}

\author{
Jin-Woo Choi ${ }^{{ }^{*}}$, Jin-Young Seo ${ }^{1}$, Soonmo $\mathrm{An}^{2}$ \\ ${ }^{1}$ South Sea Environment Research Division, Korea Institute of Ocean Science \& Technology (KIOST), Geoje, Korea \\ ${ }^{2}$ Department of Oceanography, Busan National University, Busan, Korea \\ Email: *jwchoi@kiost.ac
}

Received June 4, 2013; revised August 3, 2013; accepted August 26, 2013

Copyright (C) 2013 Jin-Woo Choi et al. This is an open access article distributed under the Creative Commons Attribution License, which permits unrestricted use, distribution, and reproduction in any medium, provided the original work is properly cited.

\begin{abstract}
This study was conducted to get some basic information on the community structure of macrozoobenthos and its temporal change at 3 sites on the Gapo artificial tidal flat within Masan Bay from March 2002 to April 2004 when 8 years passed after the construction. The Gapo artificial tidal flat was constructed by filling the dredged contaminated sediments of Masan Bay from 1990 to 1993. The surface sediment consisted of fine particles, but the grain size at the tidal flat has changed from mud to muddy sand by adding coarse particles for manila clam aquaculture by local fishermen from 2002. A total of 35 faunal species including 23 species at the upper tidal flat, 28 species at the lower tidal flat and 30 species in the tidal channel were collected during the study period. Polychaete worms were the most dominant fauna in species number and total faunal density, but mollusks were the most dominant in biomass. There was a specific species composition along tidal level. At the upper tidal flat, Prionospio japonicus, Sigambra tentaculata, and Neanthes succinea were dominant and at the lower tidal flat, $N$. succinea, P. japonicus, Corophium sinensis, and Ruditapes philipinarum were dominant while S. tentaculata, Paraprionospio coora, and C. sinensis were dominant at the tidal channel. In the feeding guild composition of the community, the surface deposit feeder (SDF) was the most abundant functional group followed by carnivores. The abundance and biomass showed a seasonal fluctuation; they decreased during summer seasonal and recovered in autumn. The Benthic Pollution Index (BPI) reflecting the trophic composition of macrozoobenthic community at each site remained in a very low level during most study period, which indicates the macrobenthic community of the Gapo artificial tidal flat has been in a disturbed environmental condition. The MDS plots also indicated that the species composition has changed seasonally and a large change in it was shown from spring to summer at all three stations. These results indicated that the benthic community in the constructed mud flat area has not reached on a stable structure until the spring of 2004 for 10 years after the artificial tidal flat construction.
\end{abstract}

Keywords: Artificial Tidal Flat; Macrozoobenthic Community; Structure Change; Masan Bay; South Korea

\section{Introduction}

Masan Bay, which is located in the southern coast of Korea, is a semi-enclosed embayment which has been receiving a large amount of industrial effluents and urban discharge from three major cities (Masan, Changwon, and Jinhae). Thus it was notorious for severe harmful algal blooms and the formation of azoic areas at the inner part of Masan Bay during summer due to benthic hypoxia since the 1980s [1]. In order to improve the degraded water quality of the bay, the Korean and local governments decided to establish a waste water treatment plant

\footnotetext{
"Corresponding author.
}

and also to remove the organically enriched sediment in Masan Bay. For the treatment of dredged sediments, a special space was required within Masan Bay. For this purpose, the Gapo artificial tidal flat area was constructed in 1993. The Gapo tidal flat area has been located in the inner part of Masan Bay and in the shallow subtidal environmental conditions before the construction of a dike and the filling of dredged sediment. So it is considered that the macrobenthic community in the subtidal Gapo area should be suffered from the annual hypoxia or anoxia during summer. This very impoverished fauna composition was reported in detail by Lim [2].

The Gapo tidal flat is very small with total area of 0.3 
$\mathrm{km}^{2}$ but it is the first and unique artificial tidal flat in Korea. However, there has been no quantitative study on the macrobenthic communities on the Gapo tidal flat during almost 8 years since the construction of the tidal flats. Thus there is no fauna data unfortunately when and how the macrobenthic fauna community was established after the construction of the Gapo tidal flat. There is also no fauna data at the Gapo area in the subtidal condition. However, we can guess that the macrobenthic community existed previously at the Gapo area which also has been suffered from the severe annual summer hypoxia, and most macrofauna in the subtidal area died off during summer season. After the construction of the Gapo tidal flat, the macrobenthic fauna on the tidal flat were free from the summer hypoxia. Thus the artificial tidal flat might play a role for a good refuge to macrobenthic organisms and also a supply source for faunal recruitments during recovery periods after hypoxia in Masan Bay.

In the most studies on the benthic communities established on artificially constructed mud flats, the main interest was focused on estimating how many years are required until the benthic communities on the tidal flats reach to the mature levels similar to those on the natural tidal flats. In the case of artificially constructed tidal flats at Sheep Island in Maine, USA, from 1988 to 1989, it took within two years from the construction that the richness of infaunal taxa, total numerical abundance, species composition, and diversity of the benthic communities developed to the similar levels with those of a surrounding reference area [3], and it took three or four years on the restored mudflat in Tees Estuary, UK [4]. However, it took more than 10 years in the benthic communities on the mud flats in the Bay of Fundy [5].

In this study, the main purpose is to monitor quantitatively the structure change of macrozoobenthic community at three stations on the Gapo artificial tidal flat and tidal channel area from March 2002 to April 2004. We also try to assess the ecological status of macrobenthic community on the artificial tidal flat whether they reached a stable condition or not by applying a benthic biotic index.

\section{Materials and Methods}

\subsection{Study Area}

The Gapo artificial tidal flat area was located as an inlet within Masan Bay in the southern coast of Korea (Figure 1). The Gapo tidal flat area has a partially opened dike and within it ca. 2 million $\mathrm{m}^{3}$ of contaminated muddy sediments at the inner part of Masan Bay had been deposited from June, 1990 to December, 1993 [6]. Finally the Gapo tidal flat area $\left(35^{\circ} 10^{\prime} \mathrm{N}, 128^{\circ} 34.5^{\prime} \mathrm{E}\right)$ with a small tidal channel was constructed by this disposal and $128^{\circ} 34^{\prime} \mathrm{E}$ $128^{\circ} 35^{\prime} \mathrm{E}$

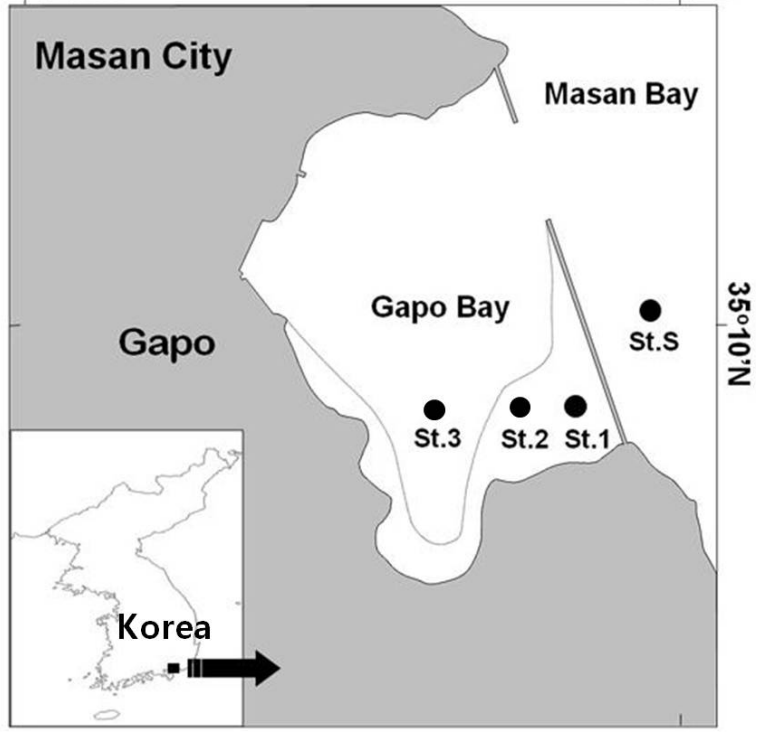

Figure 1. A map showing the Gapo artificial tidal flat and sampling stations.

its size was approximately $500 \mathrm{~m}$ in width and $600 \mathrm{~m}$ in length. The maximum tidal range of this tidal flat was ca. $2.0 \mathrm{~m}$ in spring tide.

\subsection{Fauna Samplings}

Two sampling stations (St. 1 and St. 2) were set on the upper and lower tidal flat and one sampling station at the tidal channel (St. 3) with the maximum water depth of 3 $\mathrm{m}$ (Figure 1). There was previous data on the macrofauna and benthic environmental conditions at the subtidal area with the water depth of $12 \mathrm{~m} \mathrm{[2].} \mathrm{We} \mathrm{also} \mathrm{se-}$ lected a station (St. S) to compare the macrobenthic community structure of the Gapo tidal flat.

Monitoring the water and sediment conditions and quantitative sampling of the macrobenthic fauna were conducted bimonthly at three stations (St. 1 to St. 3) between March 2002 and March 2004. The sediment of the Gapo tidal flat was too much soft to enter directly, so all sampling were carried out using a fishing boat during high tide. Salinity of the surface water was determined at station 1 with a refractor meter (Atago, S-10E). For quantitative surveys of the macrobenthic communities, four replicates of grab samples were collected using the grab sampler (covering $0.025 \mathrm{~m}^{2}$ ). The temperature of the sediment was measured by inserting a metal sensor (Testo, 905-T1) into the sediment collected at station 1, and the surface water temperature was also measured using this metal sensor. For the grain size analysis, approximately $100 \mathrm{ml}$ of the surface sediment was collected at each station. The sediment samples were sieved with a $1 \mathrm{~mm}$ opening mesh screen, and the residues on the sieve were fixed with $10 \%$ formalin solution. The T-S data and bot- 
tom DO data at station S measured by CTD meter (Seabird 19) [2] were utilized to compare the benthic environmental conditions between two sampling periods.

\subsection{Data Treatments}

In the laboratory, the grain size composition of the sediment was determined by using Sedigraph 5100 after wet sieving through $63 \mu \mathrm{m}$ mesh screen. Macrobenthic animals were sorted, identified to as species level as possible, and their individual number was counted and total wet weight of major faunal groups were measured. A species diversity ( $\mathrm{H}^{\prime}$ ) of the macrobenthic community was calculated with the data on the faunal abundance at each station. Some community parameters on species richness, density, and species diversity $\left(\mathrm{H}^{\prime}\right)$ at station $\mathrm{S}$ previously calculated [2] were used here to compare them with those on the artificial tidal flat. There was no available biomass data on the faunal groups at station $\mathrm{S}$.

In order to evaluate the healthy conditions of macrbenthic fauna community, a benthic index, BPI (Benthic Pollution Index) [7,8], was applied in this study. The values of BPI were calculated using the following equation.

$$
\begin{aligned}
\mathrm{BPI}= & {[1-(\mathrm{a} * \mathrm{~N} 1+\mathrm{b} * \mathrm{~N} 2+\mathrm{c} * \mathrm{~N} 3+\mathrm{d} * \mathrm{~N} 4) / \mathrm{d}} \\
& /(\mathrm{N} 1+\mathrm{N} 2+\mathrm{N} 3+\mathrm{N} 4)] * 100
\end{aligned}
$$

Where N1 is the abundance of carnivores and filter feeder; N2, that of surface deposit feeder; N3, that of subsurface deposit feeders; N4, that of opportunistic or pollution indicative species. The weight constants in the equation $(\mathrm{a}, \mathrm{b}, \mathrm{c}, \mathrm{d})$ are given in this study as $0,1,2$, and 3 , respectively. Thus BPI is 0 when all fauna are composed of opportunistic or pollution indicative species, while BPI is 100 when all fauna are carnivores or filter feeders. Choi and Seo [8] and Seo et al. [9] suggested that the threshold value of healthy conditions of BPI can be set as 60 . They also classified the degree of health into five different stages using this threshold index value. Thus the macrobenthic community is considered as healthy when the BPI is greater than 60, and when the BPI between 60 and 40, it is in a slightly degraded status. Likewise when the BPI is between 40 and 30 , the community is moderately degraded, and between 30 and 20, the community is in a heavily degraded, and finally the BPI is less than 20 , the community is in a severely degraded status.

To see the spatial and temporal changes in the species composition of macrozoobenthos, multivariate analyses like the cluster analysis and non-metric multidimensional scaling ordination were performed using the benthic faunal abundance data. Before the multivariate analyses, the abundance data was transformed by square root, and the similarity matrix was constructed using Bray-Curtis similarity index. All multivariate analyses were performed using the software PRIMER 5.0 released from Plymouth Marine laboratory, UK [10].

\section{Results}

\subsection{Environmental Conditions}

The water temperature of the constructed tidal flats showed a typical seasonal fluctuation pattern between $5.0^{\circ} \mathrm{C}$ in winter (January) to $27.0^{\circ} \mathrm{C}$ in summer (July to August) (Figure 2). The salinity of the surface water tended to decrease around 21 psu in summer due to heavy rainfall in the rainy season, but recovered to 34 to $35 \mathrm{psu}$ in winter. The annual fluctuations in T-S values of bottom water at the subtidal station (Stn. S) were very similar to those from tidal flat area. There was a clear summer hypoxia starting from June to September at station $\mathrm{S}$ in the subtidal region (Figure 2).

Before the sediment dredging, the surface sediment was composed of clay and silt (mud), which accounted for more than $95 \%$ of total sediment (Figure 3). Thus dredged sediments filled into Gapo inlet seemed to be mainly composed of mud particles. However, after the construction of artificial tidal flat, there occurred a regional grain size difference in the Gapo tidal flat area due to some fishermen who tried to aquaculture the manila clam by capping sand and gravels at the sediment surface of the intertidal area.

\section{T-S, Bottom DO}

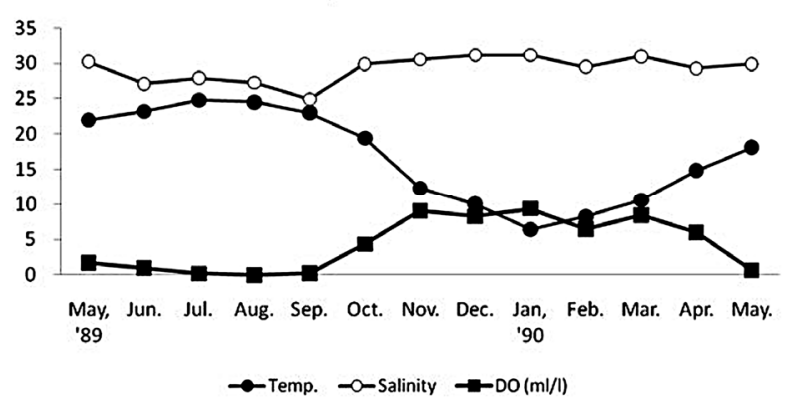

T-S

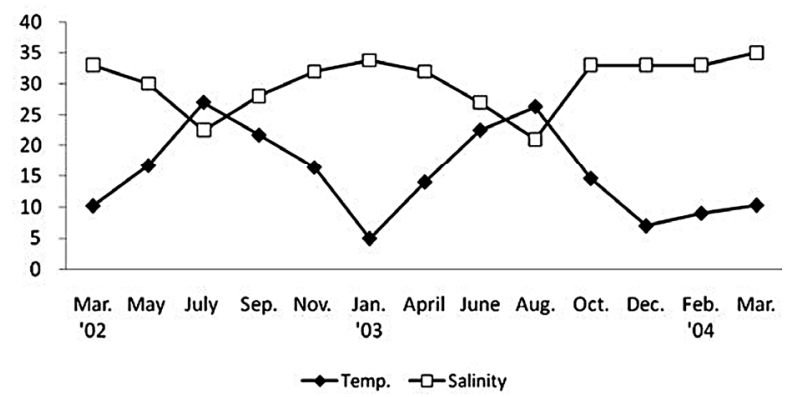

Figure 2. Temporal fluctuations of water temperature and salinity in the Gapo artificial tidal flat. 


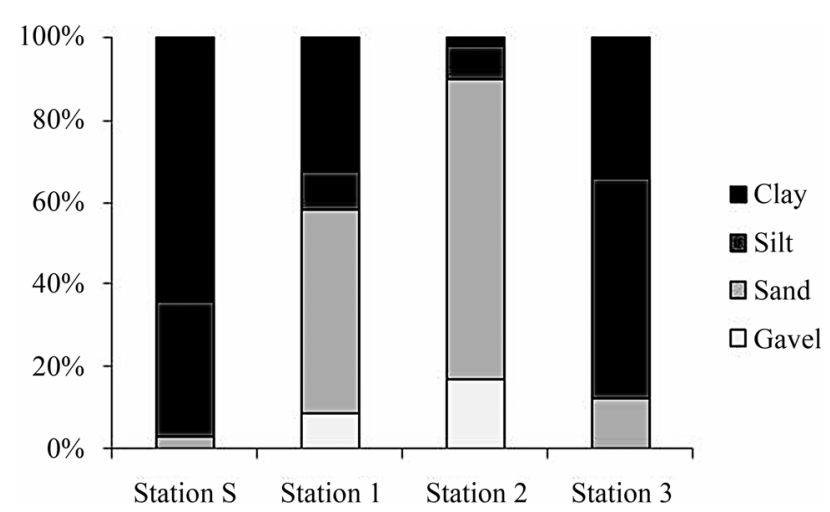

Figure 3. The percentage composition of sediment particle size at each station.

Thus the sediment of tidal flat area contained more than $50 \%$ of sand while less than $15 \%$ of sand in the tidal channel where there was little anthropogenic disturbance (Figure 3).

\subsection{Macrozoobenthos}

\subsubsection{Faunal Composition}

A total of 35 species was found during study period in the artificial Gapo tidal flat area (Table 1). They were 24 species from polychaetous annelids, 6 species from mollusks, and 4 species from crustaceans, and 1 species from cnidarians. The overall density and biomass of macrobenthos during study period were estimated to be 1194 indivi $\cdot \mathrm{m}^{-2}$ and $280 \mathrm{~g} \cdot$ wet $\cdot \mathrm{m}^{-2}$, respectively.

There was a regional difference in species richness (Figure 4). Only 18 species occurred at the upper tidal flat (station 1) compared with 26 species at the lower tidal flat or tidal channel (station 2 and 3). Mean species richness at station 1 was much lowered compared to the other two stations. There was a seasonal fluctuation in species number at each station of the Gapo tidal flat: more diverse faunal species occurred in spring, but the species number decreased rapidly in summer and slowly recovered in autumn (Figure 4).

There was a regional difference in the mean density of benthos (Figure 5). The maximum faunal density was

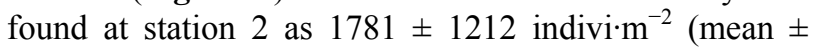
S.D.), and the intermediate density was found at station 2 as $1032 \pm 613$ indivi $\cdot \mathrm{m}^{-2}$, the lowest density occurred at station $1\left(769 \pm 460\right.$ indivi $\left.\mathrm{m}^{-2}\right)$. At the upper tidal flat and tidal channel, the density was mainly contributed to the polychaetes, but at the middle tidal flat, a large portion of faunal density was contributed to mollusks and crustaceans. There was also a seasonal fluctuation in abundance of macrobenthos at each sampling station (Figure 5).

The biomass of macrobenthos in the Gapo mud flat was prevailed by mollusks (Figure 6). Major mollusk species contributed to the total biomass were Ruditapes
Table 1. The faunal composition of macrozoobenthos occurred at each station on the Gapo artificial tidal flat area.

\begin{tabular}{|c|c|c|c|c|c|c|}
\hline \multirow{2}{*}{ Parameters } & \multicolumn{2}{|c|}{ Species } & \multicolumn{2}{|c|}{ Density } & \multicolumn{2}{|c|}{ Biomass } \\
\hline & spp. $1.3 \mathrm{~m}^{-2}$ & $\%$ & Ind. $\mathrm{m}^{-2}$ & $\%$ & gww m ${ }^{-2}$ & $\%$ \\
\hline & \multicolumn{6}{|c|}{ Station 1} \\
\hline Mollusca & 5 & 22 & 970 & 10 & 362 & 41 \\
\hline Polychaeta & 14 & 61 & 8550 & 86 & 94 & 11 \\
\hline Crustacea & 3 & 13 & 470 & 5 & 429 & 48 \\
\hline Others & 1 & 4 & 10 & 0 & 0 & 0 \\
\hline \multirow[t]{2}{*}{ Sum } & 23 & 100 & 10,000 & 100 & 886 & 100 \\
\hline & \multicolumn{6}{|c|}{ Station 2} \\
\hline Mollusca & 5 & 18 & 6960 & 30 & 6364 & 90 \\
\hline Polychaeta & 19 & 68 & 12,520 & 54 & 238 & 3 \\
\hline Crustacea & 3 & 11 & 3650 & 16 & 412 & 6 \\
\hline Others & 1 & 4 & 30 & 0 & 37 & 1 \\
\hline \multirow[t]{2}{*}{ Sum } & 28 & 100 & 23,160 & 100 & 7051 & 100 \\
\hline & \multicolumn{6}{|c|}{ Station 3} \\
\hline Mollusca & 5 & 18 & 2000 & 15 & 2745 & 92 \\
\hline Polychaeta & 20 & 71 & 9450 & 70 & 197 & 7 \\
\hline Crustacea & 2 & 7 & 1940 & 14 & 24 & 1 \\
\hline Others & 1 & 4 & 30 & 0 & 18 & 1 \\
\hline \multirow[t]{2}{*}{ Sum } & 28 & 100 & 13,420 & 100 & 2983 & 100 \\
\hline & \multicolumn{6}{|c|}{ Whole area } \\
\hline Mollusca & 6 & 17 & 3310 & 21 & 3157 & 87 \\
\hline Polychaeta & 24 & 69 & 10,173 & 66 & 177 & 5 \\
\hline Crustacea & 4 & 11 & 2020 & 13 & 288 & 8 \\
\hline Others & 1 & 3 & 23 & 0 & 18 & 1 \\
\hline Sum & 35 & 100 & 15,527 & 100 & 3640 & 100 \\
\hline
\end{tabular}

philippinarum (Adams \& Reeve), Musculus senhousia (Benson), Macoma praetexta (Martens), and Theora fragilis (Adams). The regional distribution of biomass was similar to the spatial pattern of abundance. The maximum biomass of $542.4 \pm 604.7 \mathrm{~g} \cdot \mathrm{wet} \cdot \mathrm{m}^{-2}$ was found at the middle tidal flat, and an intermediate biomass of $229.5 \pm 161.0 \mathrm{~g} \cdot \mathrm{wet} \cdot \mathrm{m}^{-2}$ was found at the tidal channel, but the smallest amount of total benthos biomass, $68.1 \pm$ $65.2 \mathrm{~g} \cdot \mathrm{wet} \cdot \mathrm{m}^{-2}$, was found at the upper tidal flat. The overall biomass decreased in summer of 2003 at all stations due to the decline of that of mollusks, but highest biomass at station 2 in June 2003 was due to the high density of Reticunassa festiva (Powy) reaching to 380 indiv $\cdot \mathrm{m}^{-2}$.

Dominant species at each station in the Gapo tidal flat during study period were different (Table 2). At station 1 in the upper tidal flat, dominant species were Prionospio japonica Okuda (33.7\%), Sigambra bassi (Hartman) (25.9\%), Neanthes succinea (Frey \& Leuckart) (10.9\%), Theora fragilis (Adams) (7.0\%), Corophium sinense Zhang (3.2\%). At station 2 in the middle tidal flat, they were Neanthes succinea (Frey \& Leuckart) (20.8\%), Ruditapes philippinarum (Adams \& Reeve) (18.8\%), Musculus 


\section{Station 1}

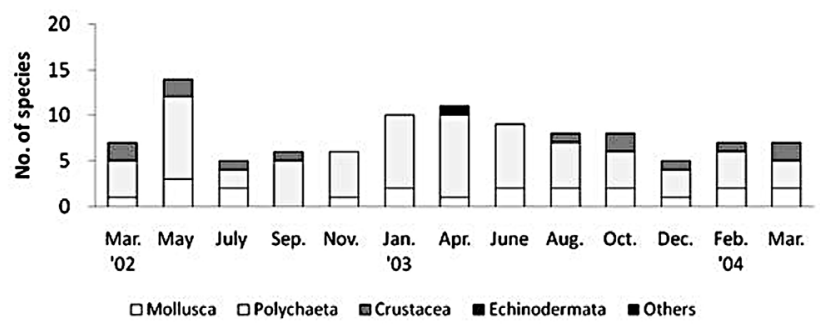

Station 3

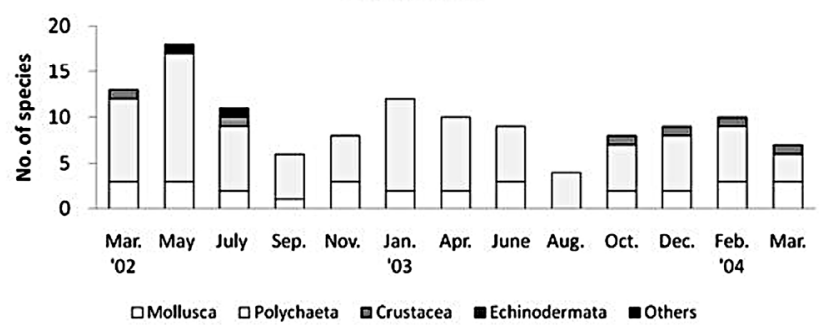

Station 2

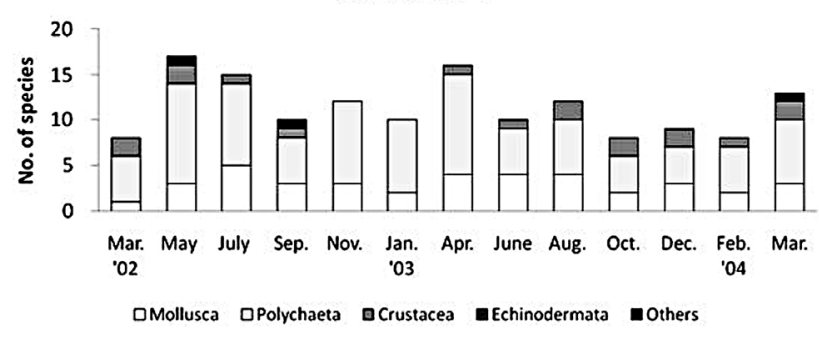

Station S

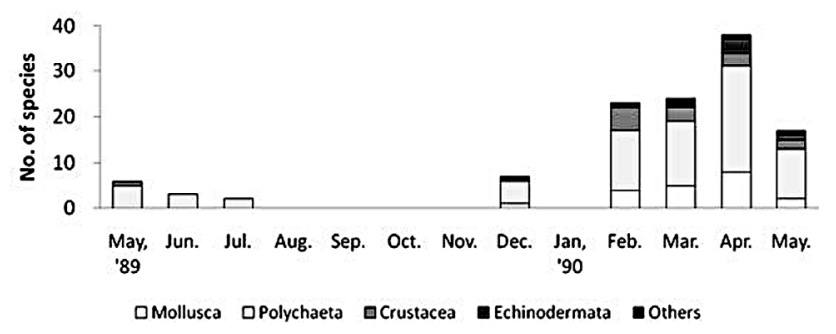

Figure 4. Species number of macrobenthos at each station of the Gapo artificial tidal flat.

Station 1

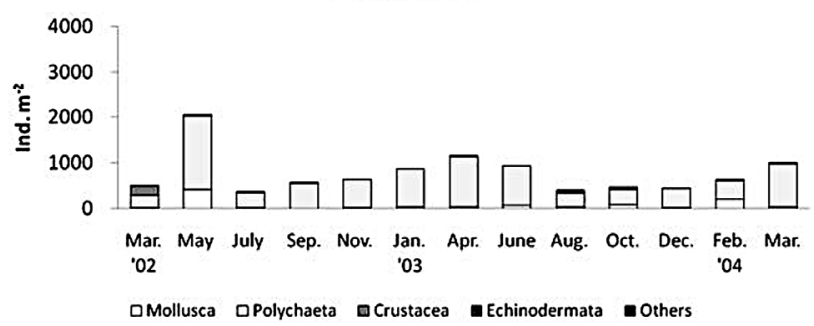

Station 2

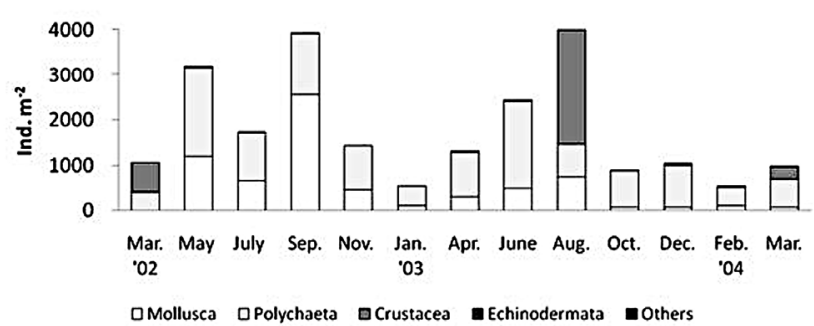

Station 3

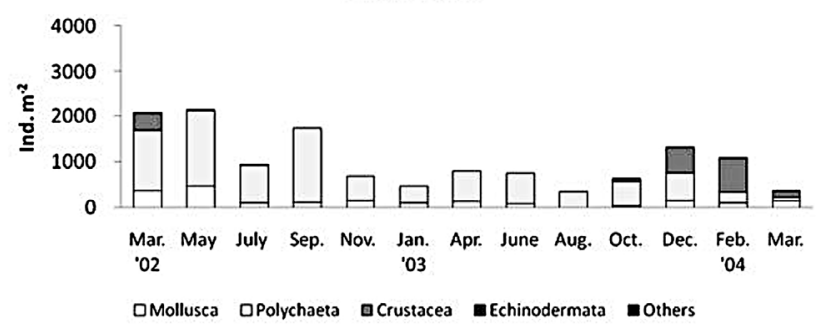

Station S

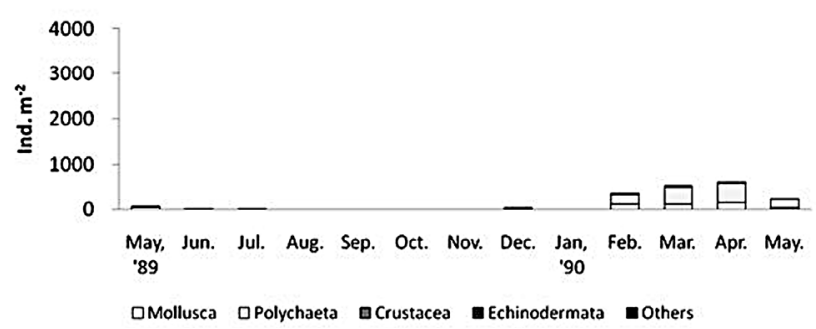

Figure 5. Density of macrobenthos at each station of the Gapo artificial tidal flat.

senhousia (Benson) (16.2\%), Corophium sinense Zhang $(4.8 \%)$. At station 3 in the tidal channel, they were different from those of tidal flat and they were typical subtidal macrobenthic species; Sigambra bassi (Hartman) (27.6\%), Paraprionospio patiens Yokoyama (26.1\%), Scoletoma longifolia (Imajima \& Higuchi) (10.5\%), Macoma praetexta (Martens) (9.6\%), Theora fragilis (Adams) $(4.6 \%)$.

There was also a seasonal change in the abundance of dominant species at each station. Dominant species at station 1, Prionospio japonica Okuda and Sigambra bassi (Hartman), showed their maximum population size in spring and summer of 2002, respectively but their densities deceased toward 2004 (Table 2). Neanthes succinea (Frey \& Leucart) dominant at station 2 also showed a typical seasonal fluctuation with low density in winter and high density in summer, but its density also decreased steadily toward 2004. Paraprionospio patiens Yokoyama and $S$. bassi dominated at station 3 also showed the similar trend in abundance.

The percentage composition of feeding types in the macrobenthic community at each station was dominated by surface deposit feeders (SDF) despite the high proportion of fine particle and organic content within sediment 
Station 1

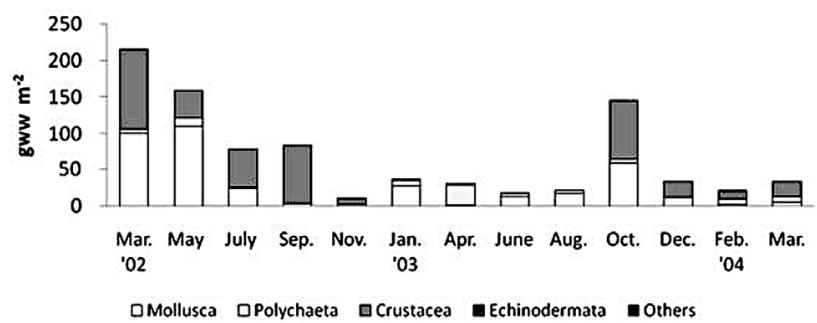

Station 2

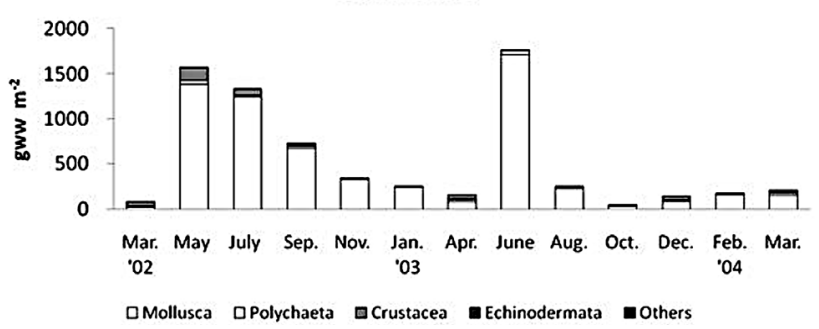

Station 3

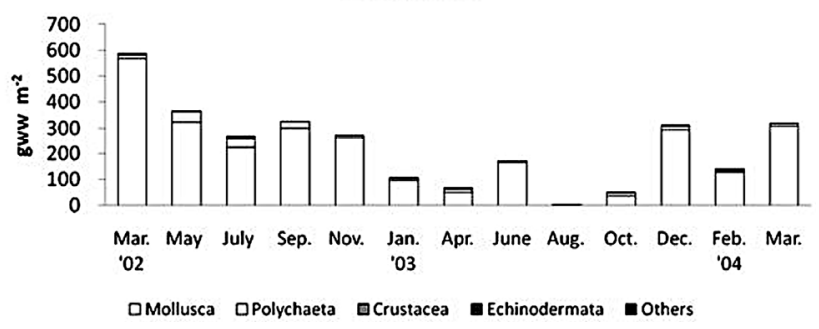

Figure 6. Biomass of macrobenthos at each station of the Gapo artificial tidal flat.

Table 2. Dominant macrobenthos occurred in the Gapo artificial tidal flat of Masan Bay during study period.

(1) Station 1

\begin{tabular}{|c|c|c|c|c|c|c|c|c|c|c|c|c|c|c|c|}
\hline Species/Date & Mar '02 & May & Jul & Sep & Nov & Jan '03 & Apr & Jun & Aug & Oct & Dec & Feb '04 & Mar & sum & $\%$ \\
\hline Prionospio japonica & 2 & 92 & 5 & 13 & 12 & 17 & 65 & 56 & 8 & 16 & 28 & 25 & 72 & 411 & 47.5 \\
\hline Sigambra bassi & 3 & 22 & 28 & 34 & 35 & 10 & 26 & 22 & 8 & 7 & 0 & 3 & 3 & 201 & 20.3 \\
\hline Neanthes succinea & 4 & 5 & 0 & 6 & 10 & 34 & 8 & 1 & 1 & 8 & 13 & 11 & 19 & 120 & 12.1 \\
\hline Theora fragilis & 0 & 39 & 1 & 0 & 0 & 0 & 3 & 2 & 1 & 6 & 2 & 2 & 2 & 58 & 5.8 \\
\hline Paraprionospio patiens & 18 & 8 & 0 & 1 & 0 & 2 & 5 & 3 & 11 & 1 & 1 & 1 & 0 & 51 & 5.1 \\
\hline Polydora ligni & 0 & 26 & 0 & 0 & 0 & 2 & 0 & 0 & 0 & 0 & 0 & 0 & 0 & 28 & 2.8 \\
\hline Corophium sinensis & 18 & 2 & 0 & 0 & 0 & 0 & 0 & 0 & 7 & 2 & 0 & 1 & 1 & 31 & 3.1 \\
\hline
\end{tabular}

(2) Station 2

\begin{tabular}{|c|c|c|c|c|c|c|c|c|c|c|c|c|c|c|c|}
\hline Species/Date & Mar' '02 & May & Jul & Sep & Nov & Jan '03 & Apr & Jun & Aug & Oct & Dec & Feb '04 & Mar & sum & $\%$ \\
\hline Neanthes succinea & 11 & 34 & 44 & 108 & 58 & 4 & 16 & 73 & 44 & 29 & 33 & 7 & 29 & 490 & 21.2 \\
\hline Prionospio japonica & 10 & 44 & 0 & 0 & 11 & 0 & 22 & 103 & 7 & 48 & 58 & 29 & 24 & 356 & 15.4 \\
\hline Corophium sinensis & 63 & 0 & 0 & 0 & 0 & 0 & 0 & 251 & 0 & 1 & 1 & 3 & 27 & 346 & 15.0 \\
\hline Ruditapes sp. & 0 & 57 & 32 & 129 & 23 & 0 & 7 & 5 & 12 & 0 & 3 & 5 & 2 & 275 & 11.9 \\
\hline Sigambra bassi & 10 & 26 & 44 & 21 & 19 & 12 & 45 & 4 & 13 & 2 & 1 & 4 & 1 & 202 & 8.7 \\
\hline Musculus senhousia & 0 & 53 & 10 & 125 & 24 & 0 & 3 & 0 & 57 & 0 & 0 & 0 & 0 & 272 & 11.8 \\
\hline Polydora ligni & 0 & 63 & 6 & 0 & 1 & 0 & 0 & 0 & 0 & 0 & 1 & 0 & 4 & 75 & 3.2 \\
\hline
\end{tabular}

(3) Station 3

\begin{tabular}{|c|c|c|c|c|c|c|c|c|c|c|c|c|c|c|c|}
\hline Species/Date & Mar '02 & May & Jul & Sep & Nov & Jan '03 & Apr & Jun & Aug & Oct & Dec & Feb '04 & Mar & sum & $\%$ \\
\hline Sigambra bassi & 9 & 72 & 28 & 52 & 38 & 19 & 27 & 32 & 15 & 6 & 17 & 1 & 1 & 317 & 23.6 \\
\hline Paraprionospio patiens & 68 & 38 & 21 & 78 & 9 & 3 & 14 & 2 & 7 & 39 & 0 & 8 & 2 & 289 & 21.6 \\
\hline Scoletoma longifolia & 20 & 8 & 21 & 29 & 2 & 5 & 8 & 2 & 12 & 6 & 8 & 5 & 5 & 131 & 9.8 \\
\hline Macoma praetexta & 32 & 16 & 8 & 13 & 11 & 4 & 1 & 7 & 0 & 2 & 2 & 6 & 11 & 113 & 8.4 \\
\hline Theora fragilis & 4 & 15 & 0 & 0 & 2 & 7 & 13 & 0 & 0 & 2 & 13 & 2 & 2 & 60 & 4.5 \\
\hline Micropodarke sp. & 14 & 9 & 7 & 1 & 4 & 2 & 1 & 3 & 0 & 1 & 0 & 2 & 0 & 44 & 3.3 \\
\hline
\end{tabular}

(Figure 7). The next dominant feeding group was carnivores. However, there were no large bodied carnivores like Glycera chirori Izuka at tidal flat sites and a few at tidal channel site. Thus most carnivores were composed 


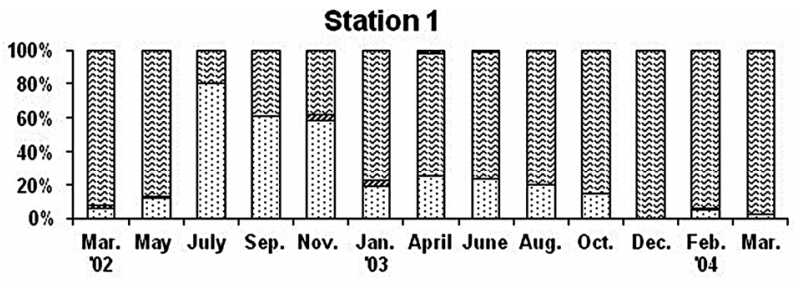

Station 2

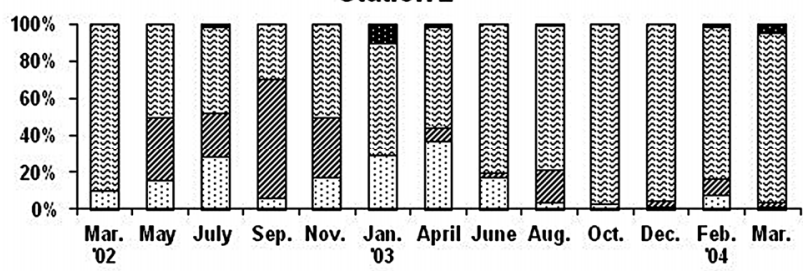

Station 3

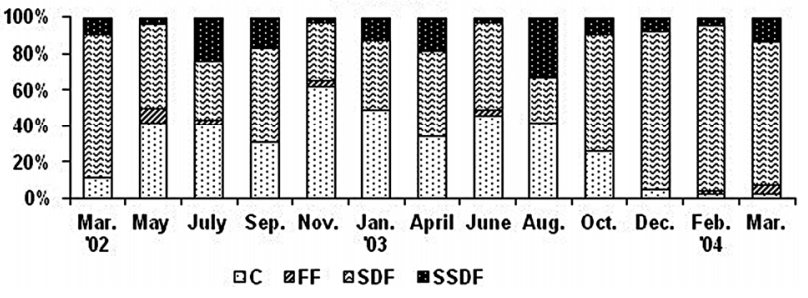

Figure 7. The percentage composition of feeding types of macrobenthos at each station of the Gapo artificial tidal flat.

of small bodied and opportunistic species.

\subsubsection{Species Diversity and Community Health Condition}

In order to measure the species diversity and to measure the health condition of benthic community, the Shannon index $\left(\mathrm{H}^{\prime}\right)$ and BPI were applied to the benthic communities in the constructed Gapo tidal flat. At the beginning of the study period, there was a difference in species diversity index $\left(\mathrm{H}^{\prime}\right)$ between sampling stations and the upper station showed a rather lower value compared with other two stations, but there was no significant difference (Figure 8). Despite the difference in species composition between station 2 and station 3, the species diversity showed very similar fluctuation pattern. As expected from the species richness, the Shannon diversity index was very low at the upper tidal station compared with other two stations, and there was no seasonal fluctuation pattern in H' values except for somewhat higher value in winter (Figure 8).

There was a clear difference in the BPI values among stations. The middle tidal flat station showed the highest values and the station at tidal channel showed the lowest values in most study period, and all three stations showed similar values at the end of study period (Figure 9). BPI values of station 2 first approached to the critical value of health condition, that is, 60 and followed by station 1 and
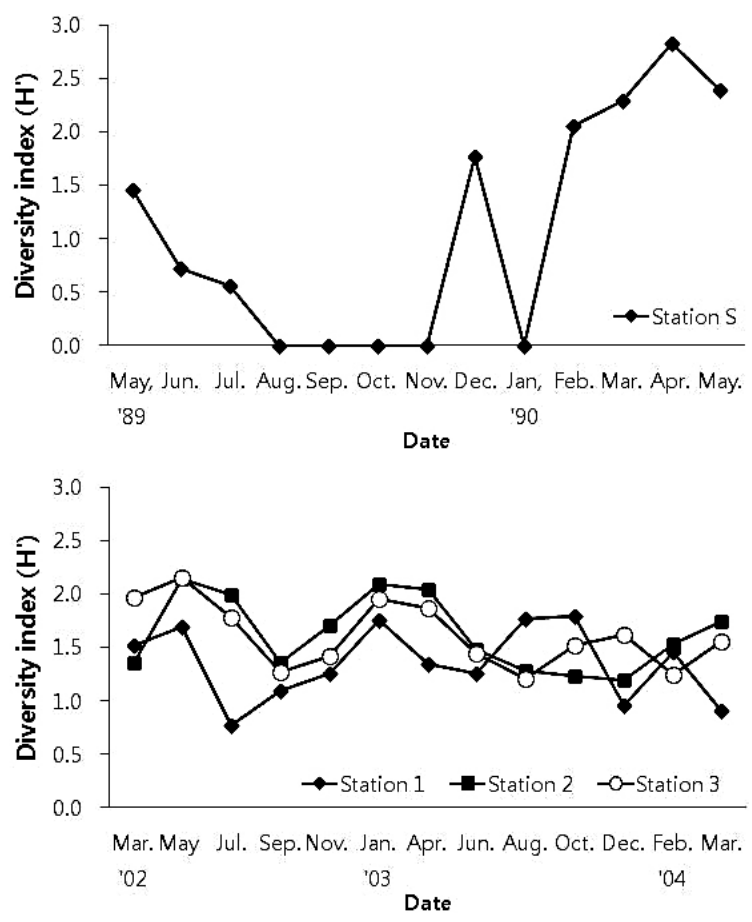

Figure 8. Species diversity (H') of the macrobenthic community at each station of the Gapo artificial tidal flat.

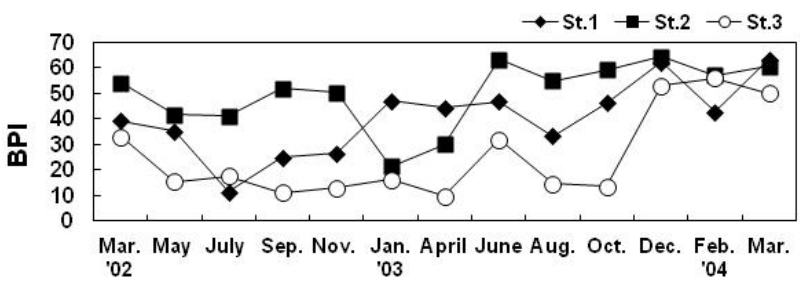

Figure 9. BPI (Benthic Pollution Index) of the macrobenthic community at each station of the Gapo artificial tidal flat.

3. At the end of study period, the benthic community in the constructed tidal flat seemed to be near the normal condition, but that of tidal channel was not. Thus the macrobenthic community was considered to be under a health condition at the end of study period, that is, the spring of 2004 after 11 years from the construction of mud flat in Gapo Bay. Although the proportion of opportunistic species at the study area decreased at the end of study period, it is not sure that these species in the constructed Gapo tidal flat will be replaced by large bodied and long life span equilibrium species after then.

The seasonal fluctuation of species composition of macrobenthos in the constructed Gapo tidal flat was also well represented at the MDS plots (Figure 10). At all stations, the species composition and abundance were largely changed during spring season; from March to May 2002 and from May to July 2003 or from April to June 2003. There was little change in species composition in summer contrast to the tidal channel station (Stn. 3). However, there was a large species change during 

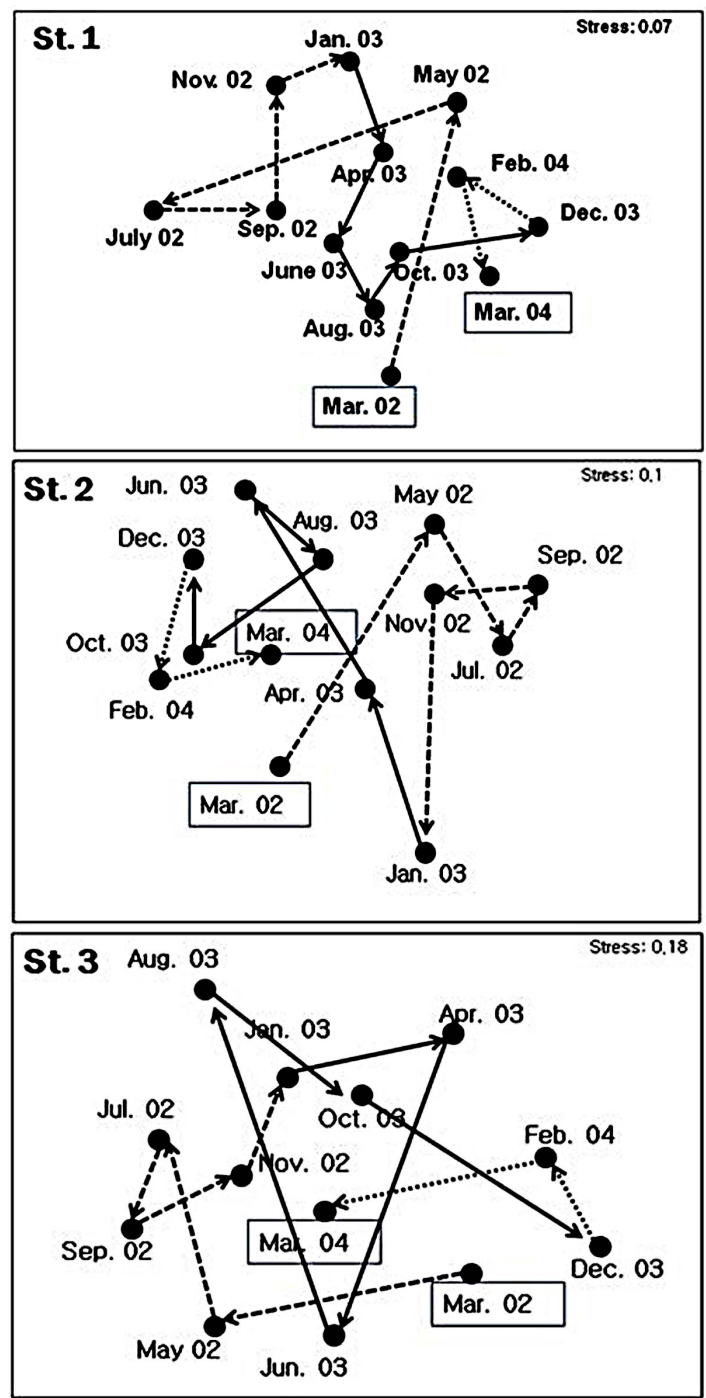

Figure 10. MDS plots showing temporal change in the macrobenthic community structure at each station.

summer from June to August 2003 at station 3.

\section{Discussions}

The artificial Gapo tidal flat was constructed by filling the dredged contaminated sediments from Masan Bay in 1994 and thus more than 8 years passed after the completion of partially opened dike construction and sediment filling until this study was conducted. It is unfortunate that there were no monitoring efforts or observations on the initial processes of benthic communities on this constructed mudflat area.

The sediment of the constructed tidal flat was mainly composed of mud which was dredged from Masan Bay. However a large amount of sand particles was added in the surface sediment of the upper and middle tidal flat to aquaculture the short neck clam (Ruditapes philippinarum (Adams \& Reeve)). They also have spread the seed- lings of the clam at the upper part of the Gapo tidal flat from 2001. Thus the sediment composition at the Gapo tidal flat was artificially changed from mud to muddy sand by fishermen's culture activity during study period. This change of sedimentary environment in the constructed tidal flat might affect the benthic community structure.

Before the construction of dike and sediment filling, the macrozoobenthic community near the coast of Gapo was suffering from severe hypoxia during summer and showed an impoverished community structure (Figures 4 and 5). This hypoxic condition in the inner part of Masan Bay was continued to summer season of 2004 [11]. The bottom DO in the inner part of Masan Bay was $0.2 \mathrm{mg}$ $\mathrm{O}_{2} / 1$ in summer of 2004 . One of the most drastic environmental changes in artificial tidal flat area was the change from hypoxic subtidal to normoxic intertidal or shallow tidal channel after the construction of artificial tidal flat in Gapo inlet. Dominant faunal group was polychaetes and species diversity was also in a lower level compared with that of the artificial tidal flat area (Figure 8).

The data on the sediment quality of the artificial Gapo tidal flat was few [12-14], and also few data on the original sediment of Masan Bay before and after the dredging $[6,15]$. There was little tissue accumulation of heavy metals in case of Ruditapes population in the Gapo tidal flat [14]. The heavy metal concentrations of sediments from the Gapo were higher than those from the Bongam sandflat located in the inner part of Masan Bay, and there was a large difference in the heavy metal contents depending on the season [12]. Thus the concentration of $\mathrm{Zn}$ in Gapo sediment fluctuated from 23.3 to 0.19 $\mathrm{mg} \cdot \mathrm{kg}^{-1}$ in Nov., 2001 and March, 2002, respectively. Those of Ni fluctuated from 4.92 to $0.46 \mathrm{mg} \cdot \mathrm{kg}^{-1} ; \mathrm{Cu}$, from 1.07 to $1.00 \mathrm{mg} \cdot \mathrm{kg}^{-1}$; $\mathrm{Cd}$, from 0.21 to $0.09 \mathrm{mg}, \mathrm{Pb}$, from 0.87 to $0.00 \mathrm{mg} \cdot \mathrm{kg}^{-1}$ in Nov., 2001 and March, 2002, respectively. The sediment was evaluated as from non-polluted to moderately polluted condition by USEPA standards and the toxicological effects of sediment ranged from ERL to ERM with copper (46.25 $\mathrm{mg} \cdot \mathrm{kg}^{-1}$ ) and zinc $\left(175.12 \mathrm{mg} \cdot \mathrm{kg}^{-1}\right)$, and below ERL with cadmium, chrome, lead, and nickel [13]. The heavy metals, especially Ni and $\mathrm{Cu}$ in surface sediments of Masan Bay exceeded the ERL but did not exceed the ERM values [15]. The mean carbon content of surface sediment of the Gapo tidal flat was estimated as $1.93 \%$, and the heavy metal contents and the tissue content of Ruditapes phillipinarum (Adams \& Reeve) were 0.57 and $0.56 \mathrm{mg} \cdot \mathrm{kg}^{-1}$ in case of $\mathrm{Cd}$; 123 and $144 \mathrm{mg} \cdot \mathrm{kg}^{-1}$ in $\mathrm{Zn} ; 28.5$ and $6.96 \mathrm{mg} \cdot \mathrm{kg}^{-1}$ in $\mathrm{Cu}$; 34.8 and $1.43 \mathrm{mg} \cdot \mathrm{kg}^{-1}$ in $\mathrm{Pb} ; 22.8$ and 0.90 in $\mathrm{Cr} ; 704$ and $8.9 \mathrm{mg} \cdot \mathrm{kg}^{-1}$ in $\mathrm{Mn}$, and 16.1 and $7.8 \mathrm{mg} \cdot \mathrm{kg}^{-1}$ in case of Ni, respectively [14]. There was no clear bioaccumulation in commercial benthos like clams in the Gapo tidal 
flat. Thus the macrobenthos of the Gapo tidal flat was considered to be slightly or moderately suffered by heavy metals.

There was a clear seasonal fluctuation in the density of macrobenthos. In summer density and biomass showed the lowest values, which indicates that the habitat may be under the highest stress in summer. But exceptionally at station 2 located lower tidal flat, the maximum density was found in summer and declined in winter. At station 1 and 3, there was a decline in density during summer in contrast to that at station 2 . In case of species richness, maximum species richness was found during spring season from April or May, but there was no large change during study period. In summer, there was a decline in species richness at station 3 located in a tidal creek probably due to the influence of hypoxia predominant in Masan Bay. From the 1980s, severe bottom hypoxic or anoxic conditions occurred in Masan Bay during summer seasons, and no fauna exist in summer seasons [16-18].

The summer decline in biomass was due to the rapid decrease of bivalves, but there appeared a biomass peak at site 2 in June 2003 by the high density of Reticunassa festiva (Powy) not occurred in other seasons. It is not clear why the density of bivalves decease during summer. The fisherman live near the artificial tidal flat introduced some seedlings of Ruditapes philippinanum (Adams \& Reeve) at the lower tidal flat near station 2 in spring season in order to aquaculture them there. Naturally muddy sediment of the artificial tidal flat was not suitable for Ruditapes population to settle down and survive there, but some people input a large amount of sand particles on the tidal flat with the purpose of bivalve aquaculture.

The dominant species on the artificial tidal flat were known as dominant species occurring at organically enriched sediments near coastal area. Paraprionospio patiens was known as occurred at only organically enriched semi-enclosed coastal areas of Korea [19]. Hediste japonica is known as a brackish species and this species was found as one of dominant species on the sandflat of Masan Bay [20]. Other dominant species like Sigambra bassi (Hartman), Polydora ligni (Webster), Theora fragilis (Adams), Heteromastus filiformis (Claparede), and Scoletoma longifolia (Imajima \& Higuchi) were known as opportunistic species responding to the organic enrichment in sediment. Among them, T. fragilis and $S$. longifolia were dominant species in the subtidal area of Masan Bay during winter and summer of 2004 [11]. In Korea, there were four coastal bays showing a severe summer hypoxia (a dead zone). Among them the artificial Lake Shihwa was known as the most notorious dead zone. One of dominant species in this artificial tidal flat, $P$. ligni Webster and Neanthes succinea (Frey \& Leucart), was also a dominant species at the subtidal soft-bottoms in the artificial Lake Shihwa [21]. Heteromastus filfi- formis (Claparede) was also dominant species at the organic enriched sediment of the Banweol tidal flat, west coast of Korea [22]. Dominant species of tidal channel of the Gapo tidal flat, Paraprionopsio patiens Yokoyama, which was recently identified from previously known as $P$. pinnata [19], has been found as major dominant species in Masan Bay before and after the summer hypoxia $[11,23]$. According to Ray, the infaunal assemblages at its early stage established on constructed intertidal mudflats at Jonesport, Maine, USA showed that some of their dominant species was composed of opportunistic species such as Streblospio benedicti (Webster), Capitella sp., Polydora ligni (Webster), and Corophium volutator (Pallas) [3].

The most dominant feeding group was surface deposit feeders in the Gapo tidal flat (Figure 7). Although SDF was the most dominant feeding type and occupied $48 \%$ and $62 \%$ of total macrobenthos in the southern shelf of Korea during autumn and winter of 2000, respectively [24], this feeding composition in the artificial tidal flat looks different with the most macrobenthic communities of finer sediments where dominant feeding group was subsurface deposit feeders (SSDF) and followed by surface deposit feeder and carnivores and filter feeders [25]. In case of shallow subtidal area off Kunsan, west coast of Korea, SSDF or burrowing polychaetes which were associated with muddy sediment with high organic matter occupied more than $48 \%$ while SDF comprised only $18 \%$ [26]. The carnivores in the Gapo tidal flat was mainly composed of small bodied opportunistic species like Sigambra bassi (Hartman). This fact suggests that benthic environments, such as heavy metals and summer hypoxia, should still impact some adverse effects on the fauna like a sensitive equilibrium species and prevent from the settlement and surviving of them.

A few biotic indices have been developed for the management of marine ecosystem though their quantitative numerical values are easy to compare the regional differences and develop management objectives in each region. Some biotic indices were calculated simplely using only macrobenthic fauna data for assessing the community health conditions. Examples are AMBI (AZTI's Marine Biotic Index) [27] and BPI (Benthic Pollution Index) [7-9]. The theoretical basis of BPI was from the ITI (infaunal trophic index) proposed by Word [28]. ITI utilized the trophic composition of macrobenthic community including suspension or filter feeders with tube, interface feeders, surface deposit feeder, and the subsurface deposit feeders utilize the organic matter within sediment. In the case of BPI, carnivores were included into ITI as a functional group and also added the opportunistic or pioneer species replaced under the severely damaged or degraded benthic environment. The BPI lacks the consistency of attributes by combining different functional 
groups such as trophic groups and life strategic groups, e.g. opportunistic species. However, it appeared that BPI reasonably well indicated the spatial gradient between macrozoobenthic communities and organic enrichment in coastal areas when BPI had been applied in the Korean coastal waters [7-9]. As the theoretical basis of the two indices complement each other and yields consistent results [8], we consider that healthy benthic community should meet the condition of BPI $>60$ and AMBI $<1.2$.

When the benthic community in the Gapo tidal flat will become or be similar to the natural mud flats? Ray reported that the infaunal assemblages of constructed mudflats by harbor dredged sediments showed a similar level of taxa richness, faunal abundance and biomass with surrounding natural tidal flats within 2 years [3]. According to Evans et al., the benthic communities of a restored mudflat in Tees Estuary, UK did not sustain sufficient abundances of important taxonomic groups (e.g. Nereis diversicolor (Muller) and Corophium volutator (Pallas)) to shorebirds compared to the undisturbed flats after three years [4]. Wilcox also noted that shorebird usage of newly restored mudflats in Upper Newport Bay, California, USA was less than natural mudflats, and this was presumably due to lower densities of their benthic invertebrate prey [29]. The infaunal communities on mudflats in the Bay of Fundy did not show total abundances equivalent to natural mudflats when there was an environmental stress like the continuing high rates of siltation occurring at the new flats [5]. In contrast to mudflat, the benthic communities on intertidal sand flats were more rapidly recovered to similar level of natural sand flats [30, 31]. However there was no benthic faunal survey in the artificial Gapo tidal flat before our study, and unfortunately it is not possible to know when macrozoobenthos could start to live and what kind of benthos could live there and how they could maintain their population and the whole community there on the artificial Gapo tidal flat. However, it seemed that the initial community structure of macrozoobenthos within the artificial tidal flat was very simple and only few opportunistic species could survive there due to the continuous disturbance by the sediment filling of dredged sediments. The constructed Gapo tidal flat is connected with Masan Bay by an opened dike and thus the tidal flat will be affected continuously by Masan Bay which has been polluted. So this will make prolong the recovery time of the benthic community in the Gapo tidal flat to a natural community level maturity over a decade.

\section{Summary and Conclusion}

The artificial Gapo tidal flat constructed by filling organically enriched and contaminated sediments dredged from Masan Bay showed very impoverished benthic communities with low species richness. During 3 years sur- vey period, only 35 species occurred at the artificial tidal flat area. The benthic communities of the artificial tidal flat showed a seasonal fluctuation in density and biomass, showing lower values in summer. Dominant species were mainly composed of opportunistic species like Neanthes succinea, Paraprionospio patiens, Sigambra tentaculata, and Theora fragilis. Despite the high sediment organic content, the benthos was dominated by surface deposit feeders not by subsurface deposit feeders. The MDS plots indicated that there was a rapid change in faunal composition during a period from spring to summer. Based on the BPI values, the health condition of benthos community in the constructed tidal flat seemed to approach to the normal status at the end of study period, April of 2004. However, macrozoobenthic community at the tidal channel site did not reach at the normal condition until the spring of 2004.

\section{Acknowledgements}

This study was partly supported by the research fund (PE99151) from Korea Institute of Ocean Science and Technology (KIOST). The authors also thank all persons for their supports in the field works. This manuscript could be improved by the kind comments from anonymous reviewers.

\section{REFERENCES}

[1] J.-S. Hong and J.-H. Lee, "Effects of the Pollution on the Benthic Macrofauna in Masan Bay, Korea," Journal of the Korean Society of Oceanography, Vol. 18, 1983, pp. 169-179.

[2] H.-S. Lim, "Ecology on the Macrozoobenthos in Chinhae Bay of Korea," Ph.D. Dissertation, National Fisheries University of Pusan, 1993, p. 311. (in Korean)

[3] G. L. Ray, "Infaunal Assemblages on Constructed Intertidal Mudflats at Jonesport, Maine (USA)," Marine Pollution Bulletin, Vol. 40, No. 12, 2000, pp. 1186-1200. http://dx.doi.org/10.1016/S0025-326X(00)00083-7

[4] P. R. Evans, R. M. Ward, M. Bone and M. Leaky, "Creation of Temperate-Climate Intertidal Mudflats: Factors Affecting Colonization and Use by Benthic Invertebrates and Bird Predators," Marine Pollution Bulletin, Vol. 37, No. 8-12, 1998, pp. 535-545. http://dx.doi.org/10.1016/S0025-326X(98)00140-4

[5] T. R. Turk, M. J. Risk, R. W. M. Hirtle and R. K. Yeo, "Sedimentological and Biological Changes in the Windsor Mudflat, an Area of Induced Siltation," Canadian Journal of Fisheries and Aquatic Science, Vol. 37, No. 9, 1980, pp. 1387-1397. http://dx.doi.org/10.1139/f80-178

[6] Masan City, "Monitoring of Masan Bay during Sediment Dredging (1990-1994)," 2004, p. 264. (in Korean)

[7] J.-H. Lee, J.-Y. Park, H.-G. Lee, H.-S. Park and D. Kim, "Environmental Assessment of the Shihwa Lake by Using the Benthic Pollution Index," Ocean and Polar Research, Vol. 25, No. 2, 2003, pp. 183-200. (in Korean) 
http://dx.doi.org/10.4217/OPR.2003.25.2.183

[8] J.-W. Choi and J.-Y. Seo, "Application of Biotic Indices to Assess the Health Condition of Benthic Community in Masan Bay, Korea," Ocean and Polar Research, Vol. 29, No. 4, 2007, pp. 339-348. http://dx.doi.org/10.4217/OPR.2007.29.4.339

[9] J.-Y. Seo, S.-H. Park, J.-H. Lee and J.-W. Choi, "Structural Changes in Macrozoobenthic Communities Due to Summer Hypoxia in Gamak Bay, Korea," Ocean Science Journal, Vol. 47, No. 1, 2012, pp. 27-40. http://dx.doi.org/10.1007/s12601-012-0003-9

[10] K. R. Clarke and R. M. Warwick, "Changes in Marine Communities: An Approach to Statistical Analysis and Interpretation," Plymouth Marine Laboratory, Plymouth, 1994, p. 144.

[11] J.-W. Choi, J.-Y. Seo, C.-H. Lee, T.-K. Ryu, C.-K. Sung, G.-M. Han and S. Hyun, "Spatial Distributional Patterns of Macrobenthic Communities during Winter and Summer in the Masan Bay Special Management Area, Southern Coast of Korea," Ocean and Polar Research, Vol. 27, No. 4, 2005, pp. 381-395. (in Korean) http://dx.doi.org/10.4217/OPR.2005.27.4.381

[12] S. An, J.-W. Choi and G. B. Kim, "Final Report on Environmental Remediation Potential of Constructed Tidal Flat in Masan Bay," Korea Science Foundation (Project No. R01-2001-00079), 2004, 89 p. (in Korean)

[13] Y. T. Kwon, "Evaluation of Heavy Metal Pollution in the Dumping Site of the Dredged Sediment, Masan Bay," Journal of the Korean Society for Marine Environmental Engineering, Vol. 7, 2004, pp. 75-81. (in Korean)

[14] I.-Y. Ahn, J. Ji, H. J. Choi, S. H. Pyo, H. Park and J.-W. Choi, "Spatial Variations of Heavy Metal Accumulation in Manila Clam Ruditapes philippinarum from Some Selected Intertidal Flats of Korea," Ocean and Polar Research, Vol. 28, No. 3, 2006, pp. 215-224. (in Korean) http://dx.doi.org/10.4217/OPR.2006.28.3.215

[15] S. Hyun, C.-H. Lee, T. Lee and J.-W. Choi, "Anthropogenic Contributions to Heavy Metal Distributions in the Surface Sediments of Masan Bay, Korea," Marine Pollution Bulletin, Vol. 54, No. 7, 2007, pp. 1059-1068. http://dx.doi.org/10.1016/j.marpolbul.2007.02.013

[16] J.-S. Hong, "Summer Oxygen Deficiency and Benthic Biomass in the Chinhae Bay System, Korea," Journal of the Korean Society of Oceanography, Vol. 22, 1987, pp. 246-256.

[17] H.-S. Lim and J.-S. Hong, "Ecology of the Macrozoobenthos in Chinhae Bay, Korea. 2. Distribution Pattern of the Major Dominant Species," Journal of the Korean Fisheries Society, Vol. 30, 1997, pp. 161-174. (in Korean)

[18] H.-S. Lim and J.-S. Hong, "Ecology of the Macrozoobenthos in Chinhae Bay, Korea. 3. Community Structure," Journal of the Korean Fisheries Society, Vol. 30, 1997, pp. 175-187. (in Korean)

[19] H. Yokoyama and J.-W. Choi, "New Records of three Paraprionospio Species (Polychaeta: Spionidae) from Korean Waters," Ocean Science Journal, Vol. 45, No. 1, 2010, pp. 55-61. http://dx.doi.org/10.1007/s12601-010-0005-4
[20] J.-Y. Seo and J.-W. Choi, "Spatial Distribution of Macrozoobenthos during Spring Season in the Estuarine Sandy Tidal Flat of Masan Bay, Korea," The Sea, Vol. 12, No. 3, 2007, pp. 211-218. (in Korean)

[21] J.-S. Ryu, J.-W. Choi, S.-G. Kang, C.-H. Koh and S.-H. Huh, "Temporal and Spatial Changes in the Species Composition and Abundance of Benthic Polychaetes after the Construction of Shihwa Dike (West Coast of Korea)," The Sea, Vol. 2, 1997, pp. 101-109. (in Korean)

[22] I.-Y. Ahn, Y.-C. Kang and J.-W. Choi, "The Influence of Industrial Effluents on Intertidal Benthic Communities in Panweol, Kyeonggi Bay (Yellow Sea) on the West Coast of Korea," Marine Pollution Bulletin, Vol. 30, No. 3, 1995, pp. 200-206. http://dx.doi.org/10.1016/0025-326X(94)00125-S

[23] H.-S. Lim, R. J. Diaz, J. S. Hong and L. C. Schaffner, "Hypoxia and Benthic Community Recovery in Korean Waters," Marine Pollution Bulletin, Vol. 52, No. 11, 2006, pp. 1517-1526. http://dx.doi.org/10.1016/j.marpolbul.2006.05.013

[24] J.-Y. Seo and J.-W. Choi, "The Macrozoobenthic Community at the Expected Sand Extraction Area in the Southern Continental Shelf of Korea," The Sea, Vol. 15, 2010, pp. 68-71. (in Korean)

[25] D. M. Maurer and W. Leathem, "Polychaete Feeding Guilds from Georges Bank, USA," Marine Biology, Vol. 62, No. 2-3, 1981, pp. 161-171. http://dx.doi.org/10.1007/BF00388179

[26] J.-W. Choi and C.-H. Koh, "The Distribution and Feeding Guilds of the Polychaete Community in the West Coast off Kunsan, Korea," Journal of the Korean Society of Oceanography, Vol. 27, No. 4, 1992, pp. 197-209.

[27] A. Borja, J. Franco and V. Pérez, "A Marine Biotic Index to Establish the Ecological Quality of Soft-Bottom Benthos within European Estuarine and Coastal Environments," Marine Pollution Bulletin, Vol. 40, No. 12, 2000, pp. 1100-1114. http://dx.doi.org/10.1016/S0025-326X(00)00061-8

[28] J. Q. Word, "The Infaunal Trophic Index," Coastal Water Research Project Annual Report, Southern California Coastal Water Research Project, El Segundo, 1978, pp. 19-39.

[29] C. G. Wilcox, "Comparison of Shorebird and Waterfowl Densities on Restored and Natural Intertidal Mudflats at Upper Newport Bay, California, USA," Colonial Waterbirds, Vol. 9, No. 2, 1986, pp. 218-226.

http://dx.doi.org/10.2307/1521216

[30] J. G. Lee, W. Nishijima, T. Mukai, K. Takimoto, T. Seiki, K. Hiraoka and M. Okada, "Comparison for Structure and Functions of Organic Matter Degradation at Natural and Constructed Tidal Flat," Japanese Society of Water Environment, Vol. 20, No. 3, 1997, pp. 175-184. http://dx.doi.org/10.2965/jswe.20.175

[31] Y. Hosokawa, "Restoration of Coastal Tidalflat in Japan," US-Japan Experts Meeting on the Management of Bottom Sediments Containing Toxic Substances, Kobe, 4-7 November 1997, pp. 1-8. 